\title{
Abstracts from the Conference on Environmental Enhancement through Agriculture
}

In November 1995 a conference on the theme "Environmental Enhancement through Agriculture" explored ways in which agriculture can improve the environment, not merely reduce the damage agriculture inflicts on it. The conference was organized by Tufts University, the American Farmland Trust, and the Wallace Institute for Alternative Agriculture. The conference took place in Boston, Massachusetts and it dealt with a wide range of what might be called "environmental services," such as providing habitat for endangered species, recycling wastes from nonagricultural sources, and producing alternatives to fossil fuels.

The program included 51 contributed papers, abstracts of which are reprinted here. The 36 papers marked with * are included in a proceedings volume. The proceedings ( 334 pp., softbound) is available for $\$ 20$ (postage included). Prepaid orders, payable to "Trustees of Tufts College," should be sent to: Center for Agriculture, Food and Environment, School of Nutrition Science and Policy, Tufts University, Medford, MA 02155.

William Lockeretz

\section{Watershed Protection}

*Watershed Protection: A Better Way. Richard I. Coombe. Watershed Agricultural Council, RR 1, Box 74, NYS Route 10, Walton, NY 13856-9751.

The program of the Watershed Agricultural Council for New York City's watersheds involves a new and better way to protect America's rural surface and ground water supplies. It is based on maintaining a well-managed agriculture as part of a comprehensive watershed protection program. The high quality of the water yielded by the Catskill and Delaware System watersheds, which is sufficient to meet federal criteria for avoiding filtration, is supported by the current low intensity land uses and land management patterns, including agriculture.

A Whole Farm Plan is the Program's main means for partnership between an individual farmer, whose involvement is voluntary, and the City. Each such plan is tailored to fit the site and the farm business. Specific farming practices to meet strict drinking water quality criteria are based on sound science and cover animal pathogens, sediment, nutrients, pesticides, and other substances with direct or indirect human health effects.

The Program's governing body and policy maker is the Watershed Agricultural Council, a not-for-profit corporation consisting of farmer and agribusiness leaders, the Commissioner of the New York City Department of Environmental Protection, and advisory members from government and private organizations.

The Program is based on the belief that farming is a preferred land use with significant long-term environmental benefits, as opposed to subdivision on the rural-urban fringe. It hopes to become a national model for watershed protection based on local decisionmaking, scientific evidence, and shared responsibility.

*The Watershed Approach to Integrating Agricultural Production and Water Quality Enhancement. Maurice G. Cook and J. Mark Rice. Department of Soil Science, Box 7619, North Carolina State University, Raleigh, NC 27607.

A system of agricultural best management practices (BMPs) was implemented on a 2,100 hectare watershed in Duplin County, North Carolina to improve water quality. The BMPs included: nutrient, pest, and animal waste management; and soil conservation practices. Both surface and ground water were continually analyzed to assess the water quality impacts.

Nutrient management plans have been developed for over $80 \%$ of the cropland. Pest management plans have been developed for over $60 \%$ of the cropland. Over one-half of all plans have been implemented. Poultry mortality composting and improved swine waste management have decreased the potential adverse effects of animal operations. A constructed wetland shows promise for pre-treatment of swine waste before land application.

Stream monitoring shows decreasing amounts of nitrate- and ammonium- $\mathrm{N}$ in the surface waters of the watershed. Ground water monitoring shows relatively high concentrations of nitrate in areas of intensive swine and poultry operations. Ground water monitoring of pesticides reveals low levels of alachlor, atrazine, and metolachlor even though large amounts of these chemicals are used on crops.

The successful implementation of agricultural BMPs appears to be improving water quality. Both stream and ground water monitoring will be continued for several years to assess the changes in water quality more definitively.

Farmer participation in project planning and execution has contributed greatly to the project's success. The project has heightened citizens' awareness of water quality issues and has promoted producer adoption of BMPs.

*Padilla Bay Proposes a Unique Community Partnership for On-Farm Agriculture and Estuary Research and Education. Colette DePhelps. Center for Sustaining Agriculture and Natural Resources, Washington State University, Pullman, WA 99164-6240.

In April 1993, the Washington State Department of Ecology, state administrator of the Padilla Bay National Estuarine

American Journal of Alternative Agriculture 
Research Reserve, partnered with Washington State University's College of Agriculture and Home Economics for three purposes: to identify and evaluate the primary environmental issues associated with the interface between farming systems and adjacent estuarine or other public receiving waters; to develop and evaluate problemsolving strategies related to these issues; and to propose educational strategies for use with the public and the agriculture community.

Outcomes of the partnership include the development of a Padilla Bay on-farm research and education program and a strategy for forming collaborative partnerships among diverse community interest groups, such as farmers and environmentalists, to identify, design, implement, and evaluate potential on-farm research and education activities. The participatory research and education strategy developed was built on the premise that the educational process is multi-directional. Not only do project participants learn from professionals, but professionals learn from project participants. The strength of the strategy lies in the development of a working coalition that energizes the creative forces of a wide range of community members to devise research and education activities that address agriculture/estuary issues of local concern and whose results will be locally acceptable and applicable.

*Operation Future: Farmers Protecting Darby Creek and the Bottom Line. Dennis W. Hall. Ohio State University Extension and Operation Future, 246 W. Fifth St., Marysville, $\mathrm{OH} 43040$.

Farmers along Big Darby Creek might have reacted negatively to the many outside interests in their agricultural community. Within just a few years, Big Darby had been declared a State Scenic River by the Ohio Department of Natural Resources, a Hydrologic Unit Area by the USDA, and one of twelve "Last Great Places" in the western hemisphere by The Nature Conservancy.

Admirably, Big Darby Creek farmers chose a different strategy. With the assistance of local Extension agents, farmers came together to form Operation Future, a nonprofit association with the mission of linking economic and environmental soundness to enhance the quality of life in the watershed. A positive sense of cooperation emerged when Operation Future farmers canoed Big Darby Creek with stream protection advocates to learn why the creek was so highly prized. Seeing many of the stream's 86 species of fish and 40 species of mussels was impressive, but the most valuable lesson was to recognize that two potentially adversarial groups, farmers and environmentalists, had more similar interests than first assumed.

Funded by the Kellogg Foundation, Operation Future has conducted a variety of watershed activities. The original canoe trip has been repeated nine times with over 300 different individuals participating. A "Farm of the Future" field day, conducted with Monsanto, drew 400 individuals. Recent annual meetings featured a prominent speaker and sold over 450 tickets.

As one of forty organizations in the Darby Partners, Operation Future has helped to advance a positive campaign that has become a national model for cooperation in ecosystem protection.

*Sustainable Farming Practices Benefit Minnesota Landscape. Dana Jackson and George Boody. Land Stewardship Project, White Bear Lake, MN 55110.

Minnesota's rural landscapes are dominated by large fields of one crop, mostly corn or soybeans. Conservationists work to preserve remnants of the original landscape and scenic areas but assume that land in agriculture offers few environmental benefits.

The Land Stewardship Project (LSP) is a Minnesota non-profit membership organization that fosters a renewed ethic of farmland stewardship and promotes sustainable agriculture. LSP works with farmers who are developing an ecosystem relationship between agriculture and the natural world. They understand that their land is part of a larger whole, and their practices, unlike those of conventional agriculture, protect the soil and water and encourage the presence of wild species of plants and animals.

Two major influences lead farmers to establish sustainable practices that enhance the environment. Holistic Resource Management $^{\mathrm{TM}}$ (HRM), is a decision making process that teaches farm families to work with neighbors and relatives to set a threepart goal that includes a vision of how they want the landscape to look far into the future. Under HRM, they also consider the effects of their farming upon culture and society. Management intensive grazing (MIG) is a method of grazing animals intensively for a short time in one area and then moving them to another area. Farmers strive for a thick, diverse mixture of grass and legumes that nourishes livestock profitably while soaking up rainwater. Minnesota landscapes benefit when row crops to feed animals are replaced by grass-based farming.

LSP's Biological, Social and Financial Monitoring Project and its projects to protect the Minnesota River watershed support both HRM and MIG. These projects are based on collaborations with other organizations and government agencies. The first involves a team of 25 people developing a kit of indicators for farmers to use in monitoring the sustainability of their farms. The second involves two elements: Clean Up Our River Environment, a grassroots effort to educate citizens about pollution of the Minnesota River; and the Chippewa River Stewardship partnership, a collaboration among diverse entities to restore wetlands and decrease pollution of the Chippewa River, a tributary of the Minnesota. Community discussion and collaboration undergird successful efforts to farm sustainably and create opportunities to change agriculture and enhance landscapes.

*Zuni River Watershed Act: An Ecosystem Plan. Gary Wooten and Ellen R. Dietrich. USDA Natural Resources Conservation Service, 6200 Jefferson Blvd. NE, Albuquerque, NM 87109 .

The Zuni River Watershed Act was passed by Congress in August 1992, with the purpose of authorizing formulation of "a plan for the management of natural and cultural resources ... within the Zuni River watershed and upstream from the Zuni Indian Reservation." Potential watershed problems identified in the Act include severe erosion, reduced productivity of renewable resources, and reduced quality and quantity of surface water.

The Work Group, the decision-making group established for carrying out the intent of the Zuni River Watershed Act, is composed of the eight entities specified in the Act. This includes Tribes, Federal and state agencies, and private landowners. The 
Work Group is assisted by a broadly representative Advisory Committee, and by ten technical teams, composed of experts in soils, range, forestry, wildlife, agriculture and cropland, hydrology and erosion, geographic information systems, archaeology, social and economic values, and cultural values. The link between the technical teams and the Work Group is a coordinator.

The final plan, due to Congress by September 30, 1997, must include a watershed survey describing current natural and cultural resource conditions, recommendations for watershed protection and rehabilitation on both public and private lands, management guidelines for maintaining and improving the natural and cultural resource conditions, and proposals for voluntary cooperative programs for plan implementation.

The Technical Teams have developed data collection methods that will be used by an interdisciplinary inventory team at sampling locations selected in each of the five subwatersheds. The sampling locations were selected using a stratified random sampling approach based on the distribution of land cover, slope, aspect, and soils within each subwatershed. The inventory will provide these teams with information on the current condition of the natural resources and will enable them to determine the types of problems that exist in different parts of the project area.

The Cultural Values and the Social and Economic Technical Teams will meet with the people in the watershed to identify the concerns and values that might affect how the project recommendations are accepted.

*Buffalo River Tributaries Watershed Project. Dennis D. Hackbart. USDA Natural Resources Conservation Service, Room 5404, Federal Office Bldg., 700 W. Capitol Ave., Little Rock, AR 72201.

The Buffalo River Tributaries Watershed Project demonstrates that application of watershed protection and water quality enhancement practices can simultaneously support agricultural activity. The Buffalo River, designated the first national river in 1972 , is a free flowing stream that meanders through the beautiful Ozark Mountains. The 150-mile river draws about one million visitors annually to participate in canoeing, camping, fishing, picnicking, and related activities. Unfortunately, this nearly pristine stream is threatened by an increase in bacteria stemming from the livestock industry, a classic example of conflict between economic and environmental concerns.

The good news is that a coalition of livestock producers, conservation districts, environmental activists, and State and Federal agencies have developed a "win-win" strategy that will enhance the water quality of the Buffalo River by reducing bacterial counts while increasing incomes of the livestock producers. The strategy involves the planning and implementation of a project funded under Public Law 83-566, the Small Watershed Act. The project includes about 230,000 acres of forest and grassland. This land supports dairy and beef cattle production and drains into the Buffalo River.

The project's dual approval plan calls for Federal cost-sharing with landowners who install animal waste and grassland management systems and streambank erosion control measures, and with local conservation districts for acquisition of conservation easements to protect riparian grasslands and forest lands. Project participation will be voluntary. Expected results of project implementation include significant reductions in bacterial counts in the Buffalo River, an increase in agricultural incomes from improved pasture production, and reduction of livestock losses from waterborne diseases.

*Marin Coastal Watershed Enhancement Project: A Cooperative Approach to Adapting Nonpoint-Source Pollution Guidelines to Local Conditions. Ellen Rilla ${ }^{1}$ and Stephanie Larson. ${ }^{2}$

${ }^{1}$ University of California Cooperative Extension, 1682 Novato Blvd., Novato, CA 94947; ${ }^{2}$ University of California Cooperative Extension, 2604 Ventura Avenue, Santa Rosa, CA 95403.

Coastal nonpoint source pollution (NPS) concerns led to the design and implementation of the Marin Coastal Watershed Enhancement Project to improve water quality, fish habitat, and natural resources in three western Marin County coastal watersheds in California through voluntary adoption of appropriate rangeland management practices developed cooperatively. Specific objectives of the project include helping landowners identify water quality problems, demonstrating existing examples of good management, providing information on management practices that maintain or enhance water quality, assisting with monitoring programs, and providing technical assistance requested by landowners.

An important aspect of this project, which is ongoing, is the cooperative effort of local government support agencies working together in a "team" approach to assist landowners, and the organization of an advisory oversight committee made up of local community members, agriculturists, regulatory and support agencies and environmental organizations. All meetings are facilitated and recorded, with group agreement reached at each step.

Project products include the development of easy to read fact sheets, a creek care guide for rural landowners, a "how-to" ranch planning workbook and video on developing a ranch conservation plan, and an accompanying report assessing watershed condition and recommending future watershed enhancement projects. Pre-project interviews of the 30 members of the advisory committee indicated that success hinged on acceptance and buy-in from landowners. Follow-up interviews 18 months later indicated that both agency staff members and landowners have become more aware of NPS and what needs to be done. Both groups also mentioned that just coming together and building consensus was an important accomplishment of the project.

Benefits derived from a coordinated watershed approach include support agencies working together rather than at odds, landowners taking control of how they will respond to NPS regulations in a coordinated fashion rather than alone, and ultimately an enhanced watershed area.

\section{Wildlife Conservation and Biodiversity}

*Collaborative Problem Solving in Cameron County, Texas: The Coexistence Committee. Duane Dale, ${ }^{1}$ Amy Purvis, ${ }^{2}$ Terry Lockamy, ${ }^{3}$ and Steve Thompson. ${ }^{4}$

${ }^{1}$ DFD Associates, 764 South East Street, Amherst, MA 01002; ${ }^{2}$ Department of Agricultural Economics, Texas A\&M University, College Station, TX 77843-2124; ${ }^{3}$ Texas Agricultural Extension Service, San Benito, TX 78586; ${ }^{4}$ U.S. Fish and Wildlife Service, Laguna Atascosa Wildlife Refuge, Rio Hondo, TX 78583. 
In an effort to protect an endangered falcon that was being released in a south Texas wildlife refuge, EPA proposed a one-county ban of all pesticides used in cotton production. This occurred in 1987, shortly after revisions to the jeopardy clause of the Endangered Species Act broadened the agency's power. Agricultural interests resorted to traditional lobbying activities and the draft proposal was withdrawn.

Facing the likelihood of a revised EPA regulation, cotton growers organized the Cameron County Agricultural and Wildlife Coexistence Committee, recruited environmentalists and wildlife managers as participants, and obtained legitimation as an ad hoc function of county government.

The committee developed its own plan for protecting the endangered falcon without totally eliminating cotton pesticides. To do so, they pooled their knowledge of the bird, of cotton production, and of pesticides, a significant step in itself given the mistrust in which environmental and agricultural interests typically hold each other. They also worked together to identify pesticides that were not in use, those used in doses determined to be no risk, and those determined to be safe to the bird if restricted to in-soil application. The U.S. EPA and the Fish and Wildlife Service were slow to respond to the committee's recommendations, but because of the members' persistence, the EPA eventually reversed the ruling that the 17 cotton pesticides jeopardized the falcon.

The most significant innovation in this case was to address pesticide regulation and endangered species protection through a collaborative local dialogue. Several elements contributed to an outcome that the participants considered positive: diversity of membership, legitimation from external authorities, a shared purpose, a flexible process, a thoughtful reframing of the problem, attention to mutual trust, anticipation of the consequences of their proposals, and development of "learning loops" as the committee monitored the impact of their recommendations. The process has been emulated within Texas and beyond, with varying degrees of success.

Point Remove Wetlands Reclamation and Irrigation Project, Conway and Pope Counties, Arkansas. Robert G. Price. USDA Natural Resources Conservation Service, Room 5404,
Federal Office Bldg., Little Rock, AR 72201.

The Point Remove Wetlands Reclamation and Irrigation Project consists of 43,100 acres in Pope and Conway Counties, Arkansas, located 50 miles northwest of Little Rock. The Arkansas Game and Fish Commission's (AG\&FC) Ed Gordon/Point Remove Wildlife Management Area (WMA) occupies 8,500 acres of the project area.

The Point Remove Wetlands Reclamation and Irrigation District, AG\&FC, and the Pope and Conway County Conservation Districts have joined to address the project area's resource problems. The major problem is the lack of a dependable water supply to provide for winter waterfowl management on the WMA and fully irrigate potentially irrigable cropland.

The project would divert water from the Arkansas River into a system of canals, streams, and pipelines to deliver irrigation water in the summer and wildlife water in the fall. Individual cooperators would provide their own farm diversion systems for removing water from the project delivery network. Irrigated land would increase from approximately 4,600 acres to 12,600 acres.

A water-level control structure on the WMA would create approximately 6,000 acres of wetland habitat for migratory and resident waterfowl, fur bearers, wading birds, and other game and nongame species of wildlife. Taintor gates will provide the capability for moist soil management, greentree reservoirs, and resting and feeding areas for waterfowl.

Wetland/Cropland Rotational Management for Improved Wetland and Sustained Agricultural Production in the Tulelake Basin. Carol Shennan. Department of Vegetable Crops, University of California, Davis, CA 95616.

Tulelake is a high mountain valley on the California-Oregon border with 44,000 acres of irrigated agriculture next to the 13,000 acre Tulelake National Wildlife Refuge. The refuge is a critical part of the Pacific Flyway and with Lower Klamath Refuge supports one million migrating waterfowl, waterfowl production of 40,000 per year, and habitat for 411 wildlife species. Concerns facing the basin include degeneration of wetland habitat, declining fish and bird populations, hypereutrophication, pesticide use next to the refuge, and declining crop productivity from build-up of soilborne pests.

Wetland/cropland rotation cycles are being proposed as a management strategy to improve wetland habitat and reduce pest levels on agricultural land, and thus reduce pesticide use. A collaborative project was developed to test the feasibility of such schemes. The project's goals are: to establish effective mechanisms for participation of federal agencies, local farmers and concerned public groups in the research process; to test whether cover crops or short-term flooding can reduce soil pathogens, weeds and nematodes while providing desirable wildlife habitat; to establish farmer/refuge managed pilot study sites to test short and long-cycle wetland/cropland rotation schemes; to compare the ability of managed wetlands and croplands to remove nutrients and pollutants from agricultural drainage water; and to quantify collectively the economic, ecological and social barriers and opportunities for implementing alternative management options.

Outcomes from the initial stages of the project will be used to illustrate the effectiveness of approaches to establish farmer involvement and agency collaboration in the research program, and to illustrate issues that arise from working in a volatile political context.

*Valley Care: Bringing Conservation and Agriculture Together in California's Central Valley. Jack M. Payne, ${ }^{1}$ Michael A. Bias, ${ }^{1}$ and Richard G. Kempka. ${ }^{2}$

${ }^{1}$ Ducks Unlimited, Inc., 9823 old Winery Place, Suite 16, Sacramento, CA 95827; ${ }^{2}$ Pacific Meridian Resources, 9823 Old Winery Place, Sacramento, CA 95827.

Valley Care is Ducks Unlimited's fiveyear comprehensive plan to expand its historical work on public wetlands in the Central Valley of California to private lands. Valley Care implements a major portion of the Central Valley Habitat Joint Venture's plan for waterfowl while directly benefitting neotropical migratory birds, threatened and endangered species, and other wildlife. Valley Care is finding ways to restore private wetlands as well as provide wildlife enhancement to private agricultural lands while continuing to add to the public wetlands base. This program is providing 
education about wildlife to a broad range of the public and is establishing new partnerships among the agricultural community, businesses, public agencies, and environmental/conservation organizations.

Valley Care provides a large area of seasonally flooded wetlands (wildlife enhanced agricultural lands), improved management of existing habitats, permanently restored natural wetlands, riparian corridors and other habitats, and improved public understanding of the needs of wildlife in the Central Valley. The project directly benefits continental populations of neotropical migratory birds, migratory waterfowl and sandhill cranes, federal- and state-listed threatened and endangered species, and a host of resident wildlife and fish.

The primary goal of Valley Care is to change the way land is managed in the Central Valley. Valley Care demonstrates ecosystem management on a landscape scale. It serves as a prototype in that it is one of the first ecosystem-level efforts to be planned and carried out on this comprehensive scale. Ducks Unlimited is using this as a model to develop other landscape-scale projects throughout North America. At the end of the five-year program for Valley Care, Ducks Unlimited expects to have dramatically altered the cultural practices associated with rice farming and other agriculture in the Central Valley. We anticipate growers to winter-flood 200,000 acres of rice fields annually, with major benefits to wildlife, and expect 30,000 acres of farmland in the Sacramento-San Joaquin Delta to be flooded each winter for wildlife habitat. These 230,000 acres of seasonal habitat will be provided at no continuing cost to the public. Through a variety of programs, an additional 100,000 acres of habitat will directly benefit from improved management. We will have restored 12,500 acres of wetlands and riparian habitats, and a comprehensive wetlands education and communications program also will be in place.

The Valley Care program is taking advantage of satellite inventory and GIS technology to inventory enhancement and restoration projects and is targeting sites for future wetland restoration. Currently, a model is being developed that allows new wetland enhancement/restoration sites to be targeted. The model uses variables such as distance to wildlife refuges, distance to contiguous wetlands, distance to water delivery systems, waterfowl population densities, soils, and land ownership. These powerful and dynamic modelling tools will be used to monitor the success of the Valley Care program.

* Establishment of On-Farm Native Plant Vegetation Areas to Enhance Biodiversity Within Intensive Farming Systems of the Sacramento Valley. John H. Anderson, ${ }^{1,2,3}$ Jennifer L. Anderson, ${ }^{1}$ Richard R. Engel, ${ }^{3,4}$ and Bruce J. Rominger: 3,5

${ }^{1}$ Hedgerow Farms, 21740 County Road 88, Winters, CA 95694; ${ }^{2}$ University of California, Davis, Primate Center, Davis, CA 95616; ${ }^{3}$ Yolo County Resource Conservation District, 221 W. Court Street Suite 8, Woodland, CA 95695; ${ }^{4}$ California Foundation for Agriculture in the Classroom; ${ }^{5}$ A.H. Rominger and Sons, 28686 Road 29A, Winters, CA 95694.

Intensive farming occupies the largest percentage of land in the Sacramento Valley of California. Intensive farming techniques, especially "clean farming" that maintains all noncrop areas without vegetation, have created farm ecosystems depleted or devoid of wildlife populations, including beneficial insects. We initiated a planting and outreach program that focused on restoring natural systems to non-cropped areas. Over the past 15 years we have tested suitability and establishment techniques for over $\mathbf{5 0}$ species of native plants from the local bioregion. Potential native plant vegetation areas common to most farms include roadsides, field borders, drainage ditches and sloughs, tail water ponds, equipment yards, and irrigation canals. Revegetation of these areas includes establishing a ground cover of native perennial grasses, sedges and rushes, and establishing native trees, shrubs, and vines matched to the type of habitat suited to the farm conditions.

Revegetation projects ongoing since 1981 clearly demonstrate improved and diverse wildlife populations on two participating farms. Additional benefits include control of noxious weeds, reduced soil erosion, enhanced water infiltration, and improved aesthetics. Negative impacts on farm production have been negligible.

The outreach programs have included over 12 formal workshops, invited lectures, farm publication articles, and numerous farm tours. Farmer interest and participation is increasing. Grant projects, including the Willow Slough Watershed Integrated Resource Management Plan, the Water Quality and Irrigation Ecosystem Management Program and the Total Resource Management and Outreach Program have recruited nearly twenty more growers to implement wildlife enhancement strategies and use their farms as outreach sites.

Fostering Biodiversity in Agricultural Systems: Integrating Landscape Ecology, Cultural Ecology and Community Participation. Luis Malaret ${ }^{1}$ and Dianne E. Rocheleau. ${ }^{2}$

${ }^{1}$ New England Science Center, 222 Harrington Way, Worcester, MA 01604; ${ }^{2}$ Clark University, Worcester, MA 01610.

Landscape pattern, a major determinant of biotic diversity and distribution, constitutes a critical nexus of human influence on biodiversity in agricultural mosaics. Complex agrarian landscapes include the interaction of humans with flora and fauna, at multiple scales of time and space, that defies analysis by traditional experimental approaches.

We focus on issues of design and methods in a landscape-level research project on biodiversity in a rural community in Kenya. This project examines the interaction between biodiversity and changing land use in current and historical contexts, promotes maintenance and possible increases in biodiversity, and assists human residents in the sustainable use of the resources. The study uses concepts and methods from population, landscape and cultural ecology, ecosystem analysis, and geographic information systems.

The project team consists of biologists and social scientists from the United States and Kenya in partnership with a rural community. The team did a preliminary survey of the biota in 1993 and conducted intensive interviews about environmental history at the extremes of an environmental gradient defined by the study site. The survey revealed distinct assemblages in the two areas: a total of 41 species of trees, 16 species of reptiles, 7 species of amphibians, and 17 species of termites, a surprisingly high diversity of study organisms considering the intensive human use and widespread land degradation. 
The conclusion outlines strategies for building upon the preliminary data to structure participatory research and land use planning.

*The Delta Farmland and Wildlife Trust. David Melnychuk. British Columbia Ministry of Agriculture, Fisheries and Food, 1767 Angus Campbell Road, Abbotsford, British Columbia V3G 2M3, Canada.

The Delta Farmland \& Wildlife Trust (DF\&WT) was established in 1993 as a nonprofit organization dedicated to the preservation of farmland and the conservation of wildlife in the Fraser River Delta ecosystem of British Columbia.

The Fraser River Delta contains some of the most productive farmland in Canada as well as internationally significant wildlife values. Both of these important resources are under threat from urban expansion of the city of Vancouver and surrounding municipalities. In response to this threat, the community of farmers, conservationists, and concerned citizens have banded together in a constructive and cooperative manner and have created a new and exciting organization. Its prime mandate is to promote and encourage sustainable and stewardship practices that not only conserve but also enhance wildlife habitat.

The board of directors of this community-based organization includes representatives from the farming sector and from local conservation groups. In its brief history, the DF\&WT has already had a positive impact on the farming/wildlife issue through several practical, on-the-ground initiatives. These initiatives can be categorized into two main groups: the first centers on demonstration of stewardship practices that sustain the agricultural resource and wildlife habitat, while the second concentrates on increasing public awareness and appreciation of the importance of farming and wildlife and the need for conserving both resources for the benefit of future generations.

Cooperation and respect between farmers and conservationists are essential for the survival of wildlife in the Fraser River Delta. The future success of the DF\&WT is largely dependent on how well it can maintain and foster this relationship.

Wildlife Conservation as a Catalyst for Implementation of Sustainable Agricultural
Practices in North Carolina. Peter T. Bromley, ${ }^{1}$ John R. Anderson, Jr., ${ }^{2}$ William E. Palmer, ${ }^{1}$ and J. Theodore Morris. ${ }^{3}$

${ }^{1}$ Department of Zoology, ${ }^{2}$ Crop Science Department, and ${ }^{3}$ Department of Forestry, North Carolina State University, Raleigh, NC 27695.

For agricultural producers and for environmentally concerned citizens, both rural and urban, wildlife conservation represents unique common ground. The bobwhite quail, an environmental barometer and symbol of the high quality of life in the southeastern U.S., has been declining for over 30 years. The demise of quail populations has alarmed sportsmen, landowners, and conservation agencies. Prominent among the hypotheses explaining the downward trend is habitat modification and intensive use of pesticides associated with post-World War II industrialization of southern agriculture. Over the past 3 years, we have employed radio-telemetry in replicated, whole farm studies as well as on-farm mesocosm experiments to measure the direct and indirect effects of modern foliar and granular pesticides on quail in realistic field scenarios, to assess the role of conservation tillage in the quail life cycle, and to evaluate the impact of habitat modifications, in the form of ditch bank and field border management, on quail numbers and behavior. Using unique methods like humanimprinted quail to quantify the quality of crop and noncropland habitats, we have demonstrated that management practices that conserve soil and water can be integrated to increase wildlife populations, particularly of quail, on commercial grain farms. The management systems that we have designed simultaneously improve crop production and enhance wildlife resources; they are economically compelling. Our work has generated regional support and unprecedented cooperation among numerous organizations with diverse interests. With farm wildlife as the catalyst, crop producers, global integrators of swine and poultry, agricultural agencies, regulatory agencies and wildlife conservation groups are helping expand our integrated farm and wildlife management ideas to a landscape scale.

*Birds of Prey and Their Use of Agricultural Fields. Kerry J. Fitzpatrick. MarineEstuarine-Environmental Sciences Program,
0220 Symons Hall, University of Maryland, College Park, MD 20742.

Agricultural fields are a viable habitat for grassland birds of prey. A review of the literature reveals several studies suggesting a management strategy to attract raptors to agricultural lands. These studies document the preference of birds of prey to forage over shorter vegetation, particularly grasses. The basis for this trend is thought to be an increased vulnerability of prey. In the Northeast, the dominant grassland prey is the meadow vole, Microtus pennsylvanicus. A balance is needed between providing enough vegetation to provide food and cover for a healthy vole population and having short enough vegetation to allow raptors to locate and capture prey more easily. Minor adjustments in standard field management practices could create the right conditions to meet both species' needs. Because the group of raptors using fields represents the largest portion of birds of prey, the management of agricultural fields offers the potential for significant habitat improvements. Specific land uses are examined where this strategy can be applied with little or no extra effort over standard practices. The agricultural benefits, benign aspects, and potential conflicts are discussed. The paper concludes with the direction of my study and other areas where more information is needed to use this approach.

*Value of Shade Coffee Plantations for Tropical Birds: Landscape and Vegetation Effects. Jeffrey David Parrish ${ }^{1}$ and Lisa J. Petit. $^{2}$

${ }^{1}$ Department of Ecology and Evolutionary Biology, Box G-W, Brown University, Providence, RI 02912; ${ }^{2}$ Smithsonian Migratory Bird Center, National Zoological Park, Washington, DC 20008.

With the imminent full conversion of the natural tropical landscape to an agricultural mosaic, tropical conservation requires a redirected effort toward alternatives offered by the agricultural ecosystems remaining after forests have disappeared. Coffee is one such alternative: it is a dominant feature in the economy and landscape of developing tropical countries that can even enhance tropical biodiversity. Grown under a shade canopy, coffee can provide critical habitat 
for tropical forest organisms where no natural forest vegetation remains. However, since the early $1980 \mathrm{~s}$, coffee has undergone a conversion from shade-managed production to cultivation under full sun conditions with removal of most or all of the shade canopy. The loss of canopy trees in a "technified" plantation represents a concomitant loss in biodiversity of forest organisms. While traditional shade coffee plantations generally support biodiversity, they vary tremendously in habitat characteristics, placement in the tropical agricultural landscape, and the resulting abilities to harbor viable populations of many forest species. In this study we evaluated the individual and combined effects of several habitat characters and landscape-level factors on the species richness and abundance of tropical resident and migratory birds in shade coffee plantations of western Panama.

We measured bird abundances, community composition, and vegetation and landscape variables within 10 plantations at varying distances from contiguous forest. As canopy cover increased in a plantation, there was a concomitant increase in the abundance of forest-wintering migrants and in the number of migrant species within a plantation. This suggests that shadier sites more closely resemble a forest in vegetation structure or in available resources, and as a result can harbor a greater diversity and abundance of migratory birds. Migrant species tended to be more abundant in coffee plantations with higher densities of flowering canopy trees. As a plantation was located further from the contiguous forest, the number of forest species shared with both the local forest interior and the forest border decreased significantly, suggesting that shade coffee has maximum conservation value when used as a multi-use buffer zone habitat along the border of protected forest areas. As distance from riparian dispersal corridors increased, the number of forest species in a plantation also declined. Multiple regression models showed that landscape and habitat factors both were important in explaining bird abundance and species richness. When managed with these habitatand landscape-level factors in consort, shade coffee plantations can provide a viable conservation tool in highly managed agricultural landscapes while meeting the needs of human economy.
Beyond Nature: Toward a Conceptual Framework that Allows for Environmental Enhancement through Agriculture. Isidor $F$. Ruderfer. Conservation Ecology and Sustainable Development Program, Institute of Ecology, University of Georgia, Athens, GA 30602-2202.

Before we can consider "environmental enhancement through agriculture," we must rethink what we mean by "environment" and "agriculture." Agriculture is treated antagonistically in most environmental discourse. I distinguish between two extremes in the popular discourse: preservationism and deep ecology. The former sees agriculture as a necessary evil whose impact can be lessened through intensifying technologies. The latter would rather see agriculture abandoned altogether.

At the root of this antagonism is something these two poles of environmentalism share: a concept of "nature" as a wellfunctioning and self-governing entity-untoitself. Individual organisms temporarily occupy previously established nodes in this web of energy, nutrient, and information flows. According to preservationism, being human is completely incompatible with being a passive node in the system; to be human is to be self-determining, self-creating, and, therefore, inherently separate from and destructive of nature. According to deep ecology, however, we do have a given role within the system, but rather than accept that passive role (as have huntergatherers, holders of this perspective sometimes claim), we have opted for the comforts and conveniences of modernity and thereby have fundamentally upset the equilibrium of the system.

In their assessments of human activity, these poles of environmentalism are forced to come to terms with "indigenous" agriculture. Deep ecology tends to see humans who are inherently different from us living "in harmony with nature." Preservationism tends to see humans who are as destructive as any others, once low population densities are taken into account. Oddly enough, evidence appears to support both interpretations: evidence indicating that these peoples who, on one hand, appear to be in passive "harmony with nature" also are actively manipulating their environments.

If we can make coherent sense of this apparent paradox, we are on our way toward an environmentalism that has room for humanity and human action. My suggestion for resolving this apparent paradox is to get rid of the concept of "nature" as a selfcontained thing-unto-itself. Rather than viewing organisms as temporary occupants of predefined roles in an already well defined web, perhaps we should view living beings as active entities that continuously and creatively develop their own roles. Thus, responsible environmental citizenship does not have to preclude active manipulation of the environment. As a result, agriculture would no longer need to be considered an environmental crime, but rather a particular mutualistic arrangement of organisms. The problem posed to us then by the necessarily interspecies ethics of such a post-'nature' would be: "How can we involve a greater variety of organisms in these and other mutualistic arrangements?"

\section{Livestock Systems}

*Environmental, Economic, and Social Benefits of Feeding Livestock on Well Managed Pasture. William Murphy, ${ }^{1}$ Joshua Silman, ${ }^{I}$ Lisa McCrory, ${ }^{1}$ Sarah Flack, ${ }^{1}$ Jon Winsten, ${ }^{1}$ David Hoke, ${ }^{1}$ Abdon Schmitt, ${ }^{1}$ and Brian Pillsbury. ${ }^{2}$

${ }^{1}$ Department of Plant and Soil Science, University of Vermont, Burlington, VT 05405; ${ }^{2}$ USDA Natural Resources Conservation Service, 18 Blair Park Road, Williston, VT 05495 .

A sustainable rural culture and its agriculture depend not only on fixing what is wrong with conventional agriculture in terms of soil erosion, pollution, and farm profitability but also on improving the farm family's quality of life and on revitalizing rural communities. One solution to the problems of farmers and rural communities lies in better use of permanent pasture. Feeding livestock on well-managed pasture can cost only one-sixth as much as feeding them in confinement. Also, it requires less labor, thereby improving farm profitability and family quality of life. As pasture-based farm profitability increases, farmers diversify their spending in ways that can result in more prosperous rural communities.

Using permanent pasture instead of tilled crops to feed livestock stops soil erosion, adds soil organic matter, and decreases 
atmospheric carbon dioxide. About 48,000 $\mathrm{kg}$ of carbon dioxide can be removed from the atmosphere and the carbon sequestered in the soil in each hectare of land converted from tilled crops to permanent pasture. Is this a way of reducing the danger of global warming from atmospheric carbon dioxide?

Surface and ground water quality has been degraded especially by soil sediments and nitrogen, phosphorus, and pesticide runoff and leaching from tilled cropland. Farmers feeding livestock on intensively managed permanent pasture grow less corn, and other tilled crops, and require less fertilizer, pesticides, and phosphoruscontaining feed supplements. These input reductions could benefit surface and ground water quality because less pollutants would enter and leave pasture-based farms.

The Pasture Management Outreach Program of the University of Vermont's Environmental Programs in Communities Project strives to help farmers learn how to use the pasture resource to its full potential to achieve these benefits. This program has helped increase the net income of more than 120 farms by as much as $350 \%$ and has saved farmers from bankruptcy. It also has resulted in farm children returning to dairy farming after they had rejected it as a career when it was being done in confinement.

The special beauty of all this is that no government incentive is needed to attract farmers to use this beneficial farming practice. Dramatically improved farm profitability and decreased labor demands that result from using well-managed pasture are the large, very attractive carrot.

*Integrated Resource Management at Work: A Case Study. Scott M. Barao. Department of Animal Sciences, University of Maryland, College Park, MD 20742.

Integrated Resource Management (IRM) is an important tool for beef cattle producers who wish to operate an efficient, profitable and sustainable enterprise in today's competitive environment. IRM provides a whole farm focus and facilitates the optimum management of farm system resources.

A 4-year participatory on-farm project was initiated to demonstrate and apply the principles of IRM within an existing beef cow-calf enterprise. The goal of the project was to design and implement management practices that improve animal and farm system performance and profitability while protecting and enhancing the surrounding environment. General farm goals were set around the assumption that management practices that increase and enhance the grazable land base would also contribute positively to environmental stewardship and farm system sustainability.

The chosen producer-owner demonstration farm lies within the Piedmont region of northeast Maryland; is rolling in its terrain; includes a significant fraction of highly erodible, loam-based soil; and is within the Deer Creek Watershed, a tributary of the Susquehanna River leading into the Chesapeake Bay. Several spring-fed streams cross the farm along with one major creek. Annual rainfall totals approximately 45 inches.

Farm goals and whole farm management plans were established at the outset. Over the duration of the project, existing crop land (tilled) was converted to permanent pasture consisting of mixed stands of grass and legumes; existing pastures were renovated and improved through the no-till addition of up to $30 \%$ legumes; permanent and temporary fence systems were installed; and a year-round grazing plan was established. In addition, innovative animal watering systems were developed to allow full utilization of grazing land while minimizing animal impact on existing streams.

Significant accomplishments include:

- Improved animal nutrition and increased farm carrying capacity (dry matter yield).

- $80 \%$ reduction in nitrogen, phosphorous and herbicide application.

- Elimination of soil erosion and soil loss.

- Reduced and controlled animal access to streams.

- Improved animal waste management.

- 90-100 day increase in grazing season with significantly reduced use of harvested, stored feeds and confinement feeding.

- Improved wildlife habitat with $30 \%$ increase in observed deer numbers and 10$15 \%$ increase in fox counts.

- $53 \%$ increase in cow herd size.

- $40 \%$ reduction in yearly cost per cow.

Overall, this project successfully demonstrated the opportunity present within agriculture to attain optimum production levels, reduce costs and achieve farm goals within the context of whole system sustainability. The best management practices that were implemented through this IRM effort resulted in a positive economic and environmental return and made optimum use of an existing renewable resource.

*The Potential of Dairy Grazing to Protect Agricultural Land Uses and Environmental Quality in Rural and Urban Settings. Bryan T. Petrucci. American Farmland Trust, Center for Agriculture in the Environment, P.O. Box 987, DeKalb, IL 60115.

Of all the new production systems that have emerged and are currently being tested, grass-based livestock systems may have the most potential to address the integrated environmental and social goals promoted by advocates of sustainable agriculture. However, the main benefit of grazing, and the primary reason that so many producers have already converted to grassbased production systems, is the potential for profits.

With this combination of environmental and economic benefits, grass-based livestock enterprises could be the answer to some of the most pressing economic and resource concerns facing rural America today, particularly in the dairy sector. Dairy grazing may be the way for small to medium-size dairy producers to remain competitive and profitable in the 21st century, especially on farms at the urban edge where conflicts with non-farm residents over environmental concerns are likely to occur. Win-win situations for both farmers and rural nonfarm residents could be created in communities willing to work cooperatively with dairy graziers.

*Enhancement of Communities with Pasturebased Dairy Production Systems. Steven $P$. Washburn, ${ }^{1}$ René J. Knook, ${ }^{1}$ James T. Green, $J r,{ }^{2}$ Gregory D. Jennings, ${ }^{3}$ Geoffrey $A$. Benson, ${ }^{4}$ James C. Barker, ${ }^{3}$ and Matthew $H$. Poore. $^{1}$

${ }^{1}$ Department of Animal Science, ${ }^{2}$ Department of Crop Science, ${ }^{3}$ Department of Biological and Agricultural Engineering, and ${ }^{4}$ Department of Agricultural and Resource Economics, North Carolina State University, Raleigh, NC 27695.

A collective vision of seasonal, pasturebased dairy farms is being developed for North Carolina. Such dairies should ensure continued local supplies of fresh milk for a 
growing population while providing economic, aesthetic, and social benefits for communities. Pasture-based dairies have lower feed costs, provide acceptable nutrient balance of nitrogen and phosphorus, and reduce concerns about odor, pollution, flies, noise, and use of fossil fuel. Seasonal, pasture-based dairies could lower stress and provide more variety and free time for farm workers. Provisions for economical land would allow such dairies to function compatibly in rural and suburban environments. Near larger urban areas, pasture-based dairies could seek long-term land leases within local park systems or special agricultural zones, thereby providing effective public green space. The aesthetic appearance of such farms would make farm vacation enterprises and tours for school children or civic clubs popular.

Profitable local family farms and the sense of community resulting from such cooperation should have lasting social and economic benefits. Differing soil types, climates, and economic conditions dictate the need for functional, local prototypes to demonstrate the feasibility of grazing-based dairies to farmers, lenders, and community leaders.

*Riparian Wetlands Then and Now: An Enhanced Environment Created by Agriculture. Quentin D. Skinner and Joseph G. Hiller. Cooperative Extension Service, Department of Rangeland Ecology and Watershed Management, University of Wyoming, Laramie, WY 82071.

A historical account of hydrological conditions of the Rocky Mountain Region is used to describe streamside vegetation as observed by Lewis and Clark and other early explorers. We compare these presettlement conditions to riparian conditions that now exist to demonstrate what agriculture has accomplished to enhance the fishery, wildlife, and recreation resources of the Western U.S. We demonstrate that ranchers alone have enhanced riparian wetland systems and have developed off-stream water sources in such a way that they are now major elements in the proper control of nonpoint pollution from western rangeland. Because of land ownership patterns and permitted rights to water resources, maintaining the integrity of ranching operations is essential to insure continued existence of present fishery and wildlife resources of the West.
*Environmental and Economic Benefits of Organic Dairy Farming in Ontario. Yetunde O. Sholubi, ${ }^{1}$ D. Peter Stonehouse, ${ }^{1}$ and E. Ann Clark. ${ }^{2}$

${ }^{I}$ Department of Agricultural Economics and ${ }^{2}$ Department of Crop Science, University of Guelph, Guelph, Ontario N1G 2W1, Canada.

Societal concerns about the long-term viability of commercial livestock agriculture reflect growing dissatisfaction with prevailing methods of livestock production. Yet ruminant livestock are the foundation on which profitable and environmentally sustainable food production systems are based. Although the environmental benefits of perennial forages are widely acknowledged, profitable economic returns require that the forages be processed through livestock. Systems that depend less on conserved feeds and confinement and more on pasture and grazing management will reveal the environmental and aesthetic advantages of ruminant-based agriculture.

A survey of eight organic dairy farms in western Ontario illustrates both the crop and livestock husbandry practices and the potential profitability of dairies that emphasize environmentally beneficial methods of milk production. For example, soil erosion and degradation were minimized through year-round soil cover with winter cereals, catch crops and perennial forages. Choosing small grains instead of corn as a feedstuff enhanced weed control while eliminating the hazards of using biocides.

Rations emphasizing perennial forages and small grains, all grown without synthetic fertilizers or biocides, supported production levels equal to the provincial average. With comparable herd sizes, organic dairies posted net returns per cow, per hectare, and per unit of labor that exceeded those from conventional dairies. The findings of this preliminary study suggest that environmentally sound agriculture can be at least as profitable as the agriculture practiced under the prevailing paradigm.

*Can Sustainable Agriculture Landscapes Accommodate Corporate Agriculture? Dennis R. Keeney. Leopold Center for Sustainable Agriculture, Iowa State University, Ames, LA 50011.
Livestock-based farming systems in the United States have rapidly moved toward the industrial model. A current example is the rapid growth in the past five years in large-scale swine confinement operations. These are characterized by dominance of outside capital and management, and by odor and pollution problems caused by concentration of swine in small areas. This development is causing concern because of the negative effects it may have on rural communities and landscapes. Promoters of large swine systems point out that the income and job potential, competitive pressures of a world economy, and economies of scale make this switch essential to retain the competitive power of local, state, regional and national economies.

The resulting debate has split the agricultural community at a time when it can ill afford to lose energy and influence by such divisive arguments. Instead, dialogue needs to be established and a fresh look should be taken of the issue. Can these types of systems fit into the landscape? Watershed planning could be the answer. Large confinement systems could be designed that fit the unique aspects of a watershed. Examples include siting to protect streams, staying clear of communities, and designing systems that can assimilate the wastes and control odors.

However, the development patterns in the affected rural landscapes are already set because of property ownership, access to utilities, etc. Thus more immediate measures must be taken so that development does not overwhelm the landscape. Measures are proposed that include grain and manure sharing and putting emphasis on developing competitive technologies so that operations of a wide range of sizes can exist together.

\section{Waste Recycling and Nutrient Management}

*On-Farm Composting of Food and Farm Wastes: Economic and Environmental Considerations. John M. Halstead, ${ }^{1}$ Terri Emmer Cook, $^{2}$ and George O. Estes. ${ }^{3}$

${ }^{1}$ Department of Resource Economics and Development, University of New Hampshire, Durham, $\mathrm{NH}$ 03824; ${ }^{2}$ Vanasse Hangen Brustlin, Inc., Watertown, MA 
$02172 ;{ }^{3}$ Department of Plant Biology, University of New Hampshire, Durham, NH 03824.

Food waste, which comprises between 8 and $25 \%$ of the national waste stream, is a legitimate target for alternatives to the traditional waste management strategies of landfilling and conversion to energy. Onfarm composting of source-separated food waste holds promise as an environmentally sound, economical alternative for waste management.

We examine whether on-farm composting can be a profitable alternative enterprise for farmers, and whether a high quality, valuable compost product can be made from source-separated fruit and vegetable waste and on-farm "waste" products, and we assess the level of technology necessary for on-farm composting. Using three case studies of on-farm composting projects in New Hampshire, cost estimates for compost production under various levels of technology are developed and analyses of compost quality resulting from different composting approaches are provided. In addition, we estimate the volume of waste generation necessary within a region to support a single on-farm composting enterprise. This research provides guidelines for deciding whether to purchase new equipment or use existing equipment for composting, for establishing tipping fees for waste generators, and for estimating the time necessary to collect, mix, and turn the compost, based on the volume of waste collected.

*Recycling Municipal Organic Wastes Through Compost Application to Agricultural Land. Thomas A. Obreza. Southwest Florida Research and Education Center, Institute of Food and Agricultural Sciences, University of Florida, P.O. Drawer 5127, Immokalee, FL 33934.

Disposal of municipal solid waste (MSW) has become complex because of difficulties in siting new landfills. Florida's MSW production is steadily increasing with its population, so other environmentally acceptable disposal means need to be explored. Composting MSW and returning it to the land recycles organics back to the site where they originated.

The importance of organic matter to soil productivity, especially in Florida's sandy soils, has long been recognized. Adding a high rate of MSW compost improves soil physical, chemical, and biological properties. Compost can increase long-term soil quality because of its stability.

Composts made from household garbage feedstock were evaluated for effects on soil properties and vegetable crop yields. When added to sand at $112 \mathrm{t} / \mathrm{ha}$, compost increased water-holding capacity about $6 \%$ by volume. When stable, mature composts were added to field soils at 27 to $112 \mathrm{t} / \mathrm{ha}$, tomato, bell pepper, crookneck squash, and watermelon grew as well or better than crops in unamended soil. Yield increases were associated with increased water use efficiency and soil fertility. When immature composts were applied, plant growth was reduced by phytotoxicity. Unstable composts matured in the soil after about 90 days. Heavy metal uptake by watermelon was negligible from compost-amended soil.

Long-term positive compost effects on soil fertility included increases in soil $\mathrm{pH}$, organic matter concentration, and soilextractable $\mathrm{P}, \mathrm{K}, \mathrm{Ca}$ and $\mathrm{Mg}$. Chemical analysis of composts showed high $\mathrm{Ca}$ and $\mathrm{Fe}$ concentrations, which may have increased retention of $\mathbf{P}$ fertilizer.

The main barriers for large-scale compost use by agriculture are production and transportation costs. There will be no incentive to produce compost if growers cannot afford to use it. If the urban community will subsidize the cost of compost distribution then its use will become more attractive.

An Assessment of Composted and Uncomposted Animal Waste Using the Multiple Goals of Waste Recycling, Soil Restoration, and Water Quality Protection. Susan S. Andrews ${ }^{1}$ and Luanne Lohr. ${ }^{2}$

${ }^{1}$ Institute of Ecology and ${ }^{2}$ Department of $A g$ ricultural and Applied Economics, University of Georgia, Athens, GA 30302.

Demonstration of agricultural practices that provide environmental protection is a necessary step in the development of strategies for a sustainable environment. Although definitions vary, sustainable practices often entail methods for chemical input reductions, soil organic matter restoration, and conscious environmental protection. Nutrient recycling is key to sustainable agroecosystem management, making farm reuse of nutrients in animal wastes very attractive. Economic and environmental comparisons of composted and non-composted animal waste management can facilitate technology adoption to meet multiple objectives for environmental enhancement through agriculture.

The evaluation of alternative systems at various scales allows decision makers to choose the best management options for their specific situation. As a determination of ecological sustainability, this study compared composted broiler litter, noncomposted broiler litter, and chemical fertilizer amendments on a vegetable crop. The results were used in comparative crop enterprise budgets to assess economic feasibility of several possible management scenarios. Finally, a thumbnail assessment method was developed for watershed level comparison of farm (crop) revenue, animal waste diversion, soil organic matter additions, and water quality risk.

Using organic matter in place of or coupled with chemical fertilizer can significantly reduce chemical usage and divert nutrients from the farm waste stream. However, the levels of nitrate- $\mathrm{N}$ and watersoluble $\mathbf{P}$ in compost pose a significant threat to surface and ground water quality. The public benefits of compost use appear greater than private economic objectives. Analyses of both on-farm and off-farm impacts should be included in the determination of feasibility, at least to the watershed scale, so that public costs and benefits can be assessed. It should be the end-users who make the final appraisal of management alternatives allowing for a tailored fit to specific needs. Taking a broader view of systems can assist in the development of winwin approaches to agriculture.

Use of Solid Waste Compost in Landscape Beautification. Allen $V$. Barker, Tara A. O'Brien, Gordon Fletcher-Howell, and Jayaram Daliparthy. Department of Plant and Soil Sciences, University of Massachusetts, Amherst, MA 01003

The University of Massachusetts has developed a cropping system by which aesthetically appealing landscapes can be produced with wildflowers in composts. Nitrogen-rich composts made from municipal solid wastes, including biosolids, are applied as mulches in which the wildflowers are seeded. A weed-suppressing barrier mulch 
of paper, sawdust, geotextiles or other permeable material is placed under the compost mulch. Newspaper is the recommended material. A one- to two-inch thick layer of compost supplies sufficient growing medium and nutrition to support plant growth with much lower fertilization than is required for conventional establishment of plantings without composts. The system can be adapted for small or large plantings in soils with a wide range of fertility. Use of leaf or yard waste compost requires fertilization to support crop growth. This system is recommended for city and park landscapes, roadsides, industrial landscapes, nurseries, home gardens, or any landscape in which a showy display of native flowering species is desired. The system promotes safe recycling of domestic wastes.

Combining Municipal Solid Waste Compost and Poultry Litter to Create a SlowRelease Organic Fertilizer and Reduce Off-Farm Nutrient Pollution. Leslie R. Cooperband. Wye Research and Education Center, University of Maryland, Queenstown, $M D$ 21658.

Animal wastes, particularly from poultry operations, are significant contributors to agricultural non-point source pollution in the Chesapeake Bay region. Nonetheless, animal waste use for on-farm nutrient supply can be an essential aspect of sustainable farming systems. Crop and manure management practices that biologically and chemically immobilize the most soluble nutrient forms could minimize nutrient loss from agricultural fields. The Delmarva's proximity to large urban centers has sparked interest in recycling urban wastes like municipal solid waste (MSW) on agricultural land. However, MSW is composted without adding nitrogen and phosphorus; both are needed to mature the compost before crop application. The combination of MSW (essentially carbon) and poultry litter (high in $\mathrm{N}$ and $\mathrm{P}$ ) could convert agricultural and urban wastes into a valuable organic fertilizer with environmentally beneficial nutrient release characteristics.

In an attempt to promote on-farm solutions to manage both rural and urban wastes, I conducted a field trial at the University of Maryland's Wye Research and Education Center on Maryland's Eastern Shore. The objectives of the study were to produce an organic amendment combining poultry litter and MSW compost that supplies adequate nutrients for crop production but minimizes the potential for off-farm contamination. In 1994, I evaluated cocomposting of poultry litter and MSW and the $N$ and $P$ release characteristics of varying combinations when applied directly to the farm field. In 1995, I compared nutrient availability and grain crop uptake in fields to which either co-composted or fresh poultry litter had been applied following legume or cereal cover crops.

Results from the composting and nutrient release studies showed that we can modify both the magnitude and the pattern of soluble $\mathrm{P}$ and $\mathrm{N}$ released from an organic waste like poultry litter by combining it with a high-carbon material like MSW, and that these modifications can be tailored to meet crop demands. The 1995 field trial showed a negative effect on both soluble soil $\mathrm{NO}_{3}^{-}-\mathrm{N}$ and corn biomass production from the combination of rye cover and poultry litterMSW compost. Plots with crimson clover had slightly higher soil $\mathrm{NO}_{3}^{-}-\mathrm{N}$ levels than rye plots over all fertility treatments. Preliminary analysis of results suggests that, if cover crops are to be used with MSW-poultry liter compost to supply crop nutrient needs, the cover crop should have a low enough $\mathrm{C}: \mathrm{N}$ ratio to prevent $\mathrm{N}$ immobilization in the soil.

*Best Nutrient Management Practices on Watersheds to Protect Water Quality in Massachusetts. Jayaram Daliparthy, Stephen J. Herbert, Thomas J. Akin, and Betsey O'Toole. Department of Plant and Soil Sciences, Bowditch Hall, University of Massachusetts, Amherst, MA 01003.

Environmental protection can be achieved through the adoption of improved nutrient management practices, especially in areas of critical environmental concern such as watersheds and coastal areas. Previous studies at the University of Massachusetts indicated that dairy manure application to perennial forages besides manure application to silage corn would greatly increase the land area for spreading, thereby decreasing the amount spread on any one field and thus reducing the potential for nitrate leaching. Such a practice could be vital on farms that have an excess of manure because of a high ratio of dairy cows to annually tilled land.
Other studies showed that the application of fertilizers such as nitrogen, phosphorus, and potassium can be avoided by adopting proper nutrient management plans and crop rotations.

In a survey of Massachusetts dairy farmers, 96\% tested their soils but only $20 \%$ calibrated their manure spreaders. A high proportion $(65 \%)$ have no manure storage facilities. Planting cover crops can prevent soil erosion and runoff, thereby reducing the potential for eutrophication of lakes, ponds, and other water resources. Fall cover crops planted after silage corn harvest can also act as nitrogen scavengers, thereby preventing nitrate leaching. Conservation tillage practices coupled with the best nutrient management strategies will have a positive impact on water quality. Adoption of best nutrient management practices will also improve soil quality, agricultural sustainability, and farm economy. However, farmers' aversion to economic risk is identified as a major obstacle to the adoption of alternative technologies. A more pro-active role from the farming community is required for the adoption of many environmentally sound and economically sustainable strategies.

\section{Energy from Agricultural Biomass}

*Environmental Enhancement Using Short-Rotation Woody Crops and Perennial Grasses as Alternatives to Traditional Agricultural Crops. Virginia $R$. Tolbert ${ }^{1}$ and Andrew Schiller. ${ }^{2}$

${ }^{1}$ Biofuels Feedstock Development Program, Oak Ridge National Laboratory, Oak Ridge, TN 37831-6422; ${ }^{2}$ Oak Ridge Institute for Science and Education, Oak Ridge, TN 37831.

Short-rotation woody crops and perennial grasses are grown as biomass feedstocks for energy and fiber. When replacing traditional row crops on similar lands, these alternative crops can provide multiple environmental benefits besides enhancing rural economies and providing valuable feedstock resources. The U.S. Department of Energy is supporting research to address how these crops can provide environmental benefits to soil, water, and native wildlife species besides providing 
bioenergy feedstocks. Research is underway to address the potential for biomass crops to provide soil conservation and water quality improvements in crop settings. Replacement of traditional erosive row crops with biomass crops on marginal lands and establishment of biomass plantations as filter strips adjacent to streams and wetlands are being studied. The habitat value of different biomass crops for selected wildlife species is also under study.

These studies have shown that in comparison with row crops, biomass plantings of both grass and tree crops increase biodiversity of birds; however, the habitat value of tree plantations is not equivalent to that of natural forests. The effects on native wildlife of establishing multiple plantations across a landscape are being studied. Combining findings on wildlife use of individual plantations with information on the cumulative effects of multiple plantations on wildlife populations can provide guidance for establishing and managing biomass crops to enhance biodiversity while providing biomass feedstocks. Data from site-specific environmental studies can provide input for evaluation of the probable effects of largescale plantings at both landscape and regional levels of resolution.

*Perennial Grasses for Energy and Conservation: Evaluating Some Ecological, Agricultural, and Economic Issues. Mark Downing, ${ }^{1}$ Marie Walsh, ${ }^{2}$ and Sandy McLaughlin. ${ }^{3}$

${ }^{1}$ Energy Division and Biofuels Feedstock Development Program; ${ }^{2}$ Energy Division; ${ }^{3}$ Environmental Sciences Division, Oak Ridge National Laboratory, P.O. Box 2008, Oak Ridge, TN 37831-6422;

Perennial prairie grasses offer many advantages to the developing biofuels industry. High-yielding varieties of native prairie grasses such as switchgrass, which combine lower levels of nutrient demand, diverse geographical growing range, high net energy yields and high soil and water conservation potential, could and should supplement annual row crops such as corn in developing alternative fuels markets. Favorable net energy returns, increased soil erosion prevention, and a geographically diverse land base that can incorporate energy grasses into conventional farm practices will provide direct benefits to local and regional farm economies and lead to accelerated commercialization of conversion technologies. Displacement of row crops with perennial grasses will have major agricultural, economic, social and cross-market implications. Thus, perennial grass production for biofuels offers significant economic advantages to a national energy strategy that considers both agricultural and environmental issues.

*The Environmental Benefits of Cellulosic Energy Crops at a Landscape Scale. Robin L. Graham, ${ }^{1}$ Wei Liu, ${ }^{1}$ and Burton C. English. $^{2}$

${ }^{1}$ Biofuels Feedstock Development Program, Environmental Sciences Division, Oak Ridge National Laboratory, P.O. Box 2008, Oak Ridge, TN 37831; ${ }^{2}$ Institute of Agriculture, University of Tennessee, P.O. Box 1071, Knoxville, TN 37901-1071.

This paper presents a broad overview of the potential environmental benefits of bioenergy from energy crops - crops grown specifically to provide energy, such as corn produced for ethanol or wood produced for power plants. The environmental benefits of using biomass for energy must be considered in the context of alternative energy options, while the benefits of producing biomass from energy crops must be considered in the context of alternative land uses.

Using bioenergy will reduce both greenhouse gas emissions and air pollution if the bioenergy displaces fossil energy. Environmental benefits are greatest for coal displacement and least for natural gas. Bioenergy also avoids the safety and waste disposal problems of nuclear energy and the land loss and fishery concerns of hydropower. Because the production and use of bioenergy emits small net amounts of greenhouse gasses and creates some air pollution, it is less benign in these respects than other renewable energy forms (wind, solar, hydro).

Significant production of bioenergy will require dedicating large amounts of land to energy crops (200-400 ha per MW of base power; $150-300$ ha per million liters of ethanol). Large-scale energy crop production will produce landscape and regional environmental benefits if perennial, low-input, cellulosic energy crops (e.g., short rotation tree crops or switchgrass) displace annual, high-input crops such as corn or soybeans.
These benefits include better wildlife habitat, reduced erosion, increased soil carbon, and improved water quality. Quantifying these benefits requires a modeling approach; empirical data at a landscape or regional scale are not available because the crops are not yet widely grown. Development and applications of such an approach demonstrate the site-specificity of environmental benefits and the importance of including economic factors in predicting them.

Biomass Energy Crops: Production Costs and Supply. Marie E. Walsh. Biofuels Feedstock Development Program, Oak Ridge National Laboratory, P.O. Box 2008, Oak Ridge, TN 37831.

Biomass energy crops are potential renewable sources of liquid fuels, power, and chemicals. The economic feasibility of these crops hinges on their prices being sufficiently low to be competitive with alternative energy feedstocks, yet high enough to provide a profit to farmers comparable to what they could earn in alternative uses for their land.

This paper presents estimates of the full economic cost (i.e., variable cash, fixed cash, and opportunity cost of owned resources including land) of producing switchgrass and hybrid poplars in six regions in the United States. Average production costs vary by region and yield, ranging from $\$ 30$ to $\$ 59 /$ dry ton for switchgrass bales, and $\$ 40$ to $\$ 65 /$ dry ton for poplar chips. Biomass prices are generally lower for switchgrass than for hybrid poplar, and are higher in the Lake States and Corn Belt than for other regions of the U.S.

Using a distribution of cropland rental rates as a proxy for the profitability of conventional agricultural crops, regional biomass supply curves are estimated. Assuming average U.S. yields of 5 dry ton/acre/ year, approximately 300 million dry tons of switchgrass could be supplied nationally at farmgate prices of less than $\$ 30 /$ dry ton. Approximately 250 million dry tons of woody crops potentially can be supplied nationally at farmgate prices of less than $\$ 40 /$ dry ton. This is enough biomass to produce 20 to 33 billion gallons of ethanol at a feedstock price of $\$ 0.36$ to $\$ 0.63 /$ gal (depending on conversion efficiency), or 600 billion $\mathrm{kWh}$ at a price of $\$ 0.04$ to $\$ 0.05 / \mathrm{kWh}$. 


\section{Metropolitan Agriculture and Farmland Protection}

Developing Nature-Based Tourism in Eastern Connecticut. Norman Bender ${ }^{I}$ and Nini Davis. $^{2}$

${ }^{1}$ Cooperative Extension System, University of Connecticut, Norwich, CT 06360; ${ }^{2}$ Northeast Connecticut Visitors District, Putnam, CT 06260.

Farmers and other owners of agricultural lands, woodlands, and open space tracts in the northeastern United States face strong and persistent economic pressures to consider selling their properties for development purposes. Changes in the structure of agriculture and the spread of suburbanization into formerly rural towns can result in the evaluation of alternative uses of lands by the owners to provide viable incomes while maintaining their properties in current or related uses.

Rural land owners are exploring opportunities that may provide additional income and employment from nature-based tourism and recreation activities. Nature-based tourism, which involves agricultural and ecological enterprises, can contribute to meeting a combination of individual and societal needs. These include promoting economic development that creates employment opportunities through sustainable resources; maintaining a quality of life that includes preserving farmlands, open space and rural viewscapes; and maintaining economically and socially viable rural communities.

The paper describes a regional tourism development project designed to:

- Develop awareness of opportunities in the Eastern Connecticut region for naturebased tourism activities through a field survey, educational materials and workshops.

- Promote the region as a family-oriented tourist destination focusing on agricultural and natural resources by developing and distributing guides on farming, biking and hiking attractions.

- Coordinate selected outdoor recreational activities in the Northeast and Southeast Connecticut tourism districts, including a 50-mile bike tour and a hiking event.

- Achieve these objectives while developing a network of local farms, businesses, community officials, and agricultural and ecological organizations committed to further development of tourism while preserving the region's natural attributes.

The nature-based tourism development project initiated by the Northeast Connecticut Visitors District takes a collaborative approach involving Northeast and Southeast Connecticut visitors/tourism districts, agricultural and ecological businesses, and the University of Connecticut Cooperative Extension System. We provide an overview of the region's geography and economy, and describe the project's objectives, methods, and results (products and outcomes). We discuss the project's implications for developing a sustainable agricultural and ecological tourism industry in the northeastern United States that contributes toward maintaining the region's agricultural and natural resources.

*Empirical Evidence of Public Preferences for Farmland Preservation. Jeffrey Kline and Dennis Wichelns. Department of Environmental and Natural Resource Economics, University of Rhode Island, Kingston, RI 02881.

Environmental amenities such as wildlife habitat, scenic vistas, and cultural values have become scarcer relative to food and fiber in developed countries. As a result, public concern has shifted from increasing agricultural production as a policy goal toward protecting and enhancing the quality of the rural environment. Conflicts arise between private and public interests when the decisions of landowners fail to provide socially optimal amounts of environmental amenities. Public policies can reduce these conflicts by encouraging landowners to manage farmland in a socially desired manner.

Choosing appropriate policies requires accurate information describing public preferences for the environmental amenities provided by farmland. We use qualitative information provided by focus groups and survey data from a sample of Rhode Island residents to identify and compare socially valued environmental amenities associated with farmland and other open space lands. The results provide empirical evidence that the public perceives significant environmental amenities associated with farmland, such as wildlife habitat and groundwater protection.

Rhode Island residents believe that protecting the environmental amenities associated with farmland is more important than protecting local agricultural production or maintaining farming as a way of life. In Rhode Island, public preferences for preserving farmland compare favorably with preferences for preserving other types of open space. The characteristics of these preferences regarding specific amenities are useful in designing public policies that protect and enhance the environmental benefits provided by farmland and open space.

*Protecting Important Natural Areas, Wildlife Habitat and Water Quality on Vermont Dairy Farms through the Vermont Farmland Protection Program. Alex Considine, ${ }^{1}$ John Roe, ${ }^{2}$ and Kate Willard. ${ }^{3}$

${ }^{1}$ Vermont Land Trust, 8 Bailey Ave., Montpelier, VT 05602; ${ }^{2}$ The Nature Consenvancy, 27 State St., Montpelier, VT 05602; ${ }^{3}$ Vermont Department of Agriculture, Food \& Markets, 116 State St., Drawer 20, Montpelier, VT 06520.

Vermont has an active farmland conservation program designed to protect the state's best agricultural land and, to the extent possible, important natural areas, recreational sites and historical resources. The Vermont Department of Agriculture and the Department Fish and Wildlife, Vermont Land Trust and The Nature Conservancy have worked together in the state's most active farming areas to protect high quality farmland associated with critical wildlife habitat along wetlands and river banks in three separate conservation projects. The objectives in these projects were: to conserve good quality farmland to enhance the farm's viability; to protect critical wildlife habitat; to enhance water quality; to protect state threatened/endangered species; and to provide public access for hunting and fishing.

The result has been permanent conservation of four viable family dairy farms that also provide direct environmental benefits. A variety of methods have been used, including easement and fee purchase, easement donation, and regulatory requirements for building setbacks. In all the properties, vegetated buffer strips either were established or were permanently preserved for the purposes stated above. In some cases, cropped grassland buffers were created, designed to reduce runoff to open waters. In other cases, undisturbed buffers, either existing or created, were needed to insure protection of critical 
habitats or waterfowl nesting areas. Providing public access for hunting on some of the buffers was particularly relevant because the agricultural land provides important staging areas for migrating waterfowl.

*Regional Farmers' Market Development as an Employment and Economic Development Strategy. John S. Nettleton. Cornell University Cooperative Extension, New York City Programs, 16 E. 34 St., 8th Fl., New York, NY 10016.

Cornell University Cooperative Extension/New York City Programs has joined with Extension programs in surrounding counties and with not-for-profit groups based in New York City to form the "New Farmers/New Markets" Program. This is an effort to: 1) expand participation in existing and newly established farmers' markets (25 presently in NYC); 2) train neighborhood residents, primarily youth, to grow crops for market as part of a team-building and skills development effort based in camps and retreats surrounding the city, and; 3) train new immigrants and interested adults in farm market production, with primary emphasis on organic and sustainable production methods.

The efficacy of this strategy on a regional scale is examined as a demonstration that builds on the organizational advantages of each participant group. The Extension education network is statewide and longstanding; the not-for-profit summer facilities can benefit from added programs during the summer, reduced operating costs from fresh fruits and vegetables grown on site, and the potential for year-round program expansion with neighborhood residents in the city. For participating youth, the program provides an opportunity to gain an understanding of the food system, increase science and mathematics literacy skills in a hands-on and experiential process, and learn social and marketing skills through face-to-face marketing of the produce they have grown.

Long-term planning will engage civic grouping representing new immigrants, where recent traditions of agriculture offer the potential for participation and a variety of niche marketing options keyed to farmers' markets in multicultural settings. Fallow and productive farmland throughout the metropolitan area offers near-term potential for groups of cooperating producers, while the labor-intensive aspect of organic production avoids some start-up capital requirements of traditional production agriculture. The program aims to link local and regional groups involved in farm market production with land preservation groups and trusts active throughout the region.

Urban to rural linkages already established and underway are discussed, showing concrete examples of interagency and group collaboration.

*Community Food Security, Agriculture, and the Environment: A Massachusetts Perspective. Hugh M. Joseph. School of Nutrition Science and Policy, Tufts University, Medford, MA 02155.

Community Food Security (CFS) is an emerging strategy to address hunger, access to food, and environmental concerns through a comprehensive food systems approach. It is an adaptation of the food security model, and integrates agriculture, food supply, nutrition and other local food system elements with broader socioeconomic objectives at the community level. An important goal of CFS is to link concerns such as environmental protection and preservation of local farming with urbanbased priorities such as reducing hunger and expanding access to affordable food in the inner city.

Examples of established programs that fit the CFS model include farmers' markets, community gardens, and inner-city cooperative supermarkets. Some recent initiatives involve more integrative strategies. For example, the Western Massachusetts Food Bank developed a Community Supported Agriculture farm that provides fresh produce for hundreds of paying households while supplying thousands of pounds of free food each season to hungry people. Similarly, the Farmers' Market Nutrition Program promotes better nutrition for WIC recipients while supporting farmers' markets in low-income urban areas. These programs demonstrate the benefits of farming in states such as Massachusetts to urban residents, and they build farmers' support for problems that affect the city and the poor.

CFS holds the promise of bringing together usually disparate interests to address food system concerns in a more integrated manner. CFS will thereby demonstrate the environmental benefits of local agriculture to urban constituencies while broadening support for these issues among diverse interests including community development, anti-hunger, environmental, and public health/nutrition groups. It will similarly reduce the relative isolation of agricultural issues among groups involved with other environmental or food system concerns and programs.

With declining farming and rural populations and the resulting decline in their political representation, agriculture relies increasingly on urban-based policy makers and consumers for support. In Massachusetts, the urban vote has been critical for programs that preserve farmland, help farmers address environmental problems, and provide marketing and other economic opportunities that sustain local agriculture. Strategies that maintain consumer as well as local, state, and federal support for regional agriculture are critical elements for this sector's long-term sustainability. CFS advocates and associated anti-hunger, environmental, and community development groups can articulate the importance of community-based food and farm projects that expand awareness of, and support for, Massachusetts agriculture and related environmental benefits among the public and politicians.

Land Protection as Environmental Enhancement Through Agriculture. Thomas E. Duston. Department of Economics, Keene State College, 229 Main Street, Keene, NH 03435-2001.

Land protection, defined as the permanent removal of parcels or corridors of land from development consideration, is an important objective for a variety of conservation interests. These interests include large, well-established organizations like the Sierra Club, the Conservation Law Foundation, and the Audubon Society; international political movements such as the "Greens"; local organizations interested in pathways, greenways, and parks; and the growing number of economists, environmental biologists, and regional planners pursuing the elusive concept of "sustainable economic growth." Land protection clearly enhances the environment, whether by allowing the development of hiking trails, by creating wildlife corridors, or simply protecting aesthetically pleasing landscapes. 
The question is: How can this type of environmental enhancement be related to agricultural practices?

The concept that connects land protection through agriculture to environmental improvements is that of agricultural potential. Land protection programs represent current environmental enhancement that comes not through current agriculture practices, but through the saving of the future agricultural potential of the land. Although admittedly it might not be the easiest thing politically to convert a town forest into a cornfield sometime in the future, it would be far more difficult to convert a piece of land that had become a shopping mall instead of a town forest. The shopping mall greatly restricts the future options on the land. In addition, we cannot anticipate what new methods of agriculture might be based in protected areas. Among these might be low impact "shade horticulture," hydroponic gardening in wetlands, or even the discovery of additional forest plants with medicinal uses.

In any case, the protection of the agricultural potential of the land as a current benefit of land protection seems to be ignored in cost-benefit calculations of the value of land protection. This paper takes the various methods of land protection-donation, easement, trust, land swap, purchase, bargain sale, and lease-and determines how the inclusion of agricultural potential affects the benefits and costs associated with the particular land protection method. Not surprisingly, the type of land protection method, as well as alternative tax structures and the nature of the land itself, are important variables in the analysis of land protection as environmental enhancement through the "banking" of agricultural potential.

\section{A Conjoint Analysis of Farmland Protection Under a Purchase of Development Rights Program. Maria C. Centenera and John Mackenzie. Department of Food and Re- source Economics, College of Agricultural Sciences, University of Delaware, Newark, DE 19717.}

Farmland can be thought of as a heterogeneous good providing various benefits to residents of an area through combinations of its constituent attributes. Policy makers in the state of Delaware recently funded a statewide farmland purchase of develop- ment rights (PDR) program in an effort both to influence land use patterns and to enhance the state's agricultural industry. Residents benefit from not only the economic aspects of agriculture, but also the non-market environmental aspects.

While economic benefits are often reflected in market prices for farmland parcels, environmental benefits are more difficult to calculate. Consequently, PDR program officials lack objective and precise criteria to account for the broader environmental benefits of alternative farms. More generally, PDR programs themselves are not readily evaluated or justified by conventional benefit-cost criteria.

This study explores individual residents' preferences for protected farmland using conjoint analysis. This type of analysis allows for the calculation of willingness to pay for different farmland attributes, including non-market environmental attributes. Farmland attributes (and corresponding levels within each attribute) considered in this study are: farm parcel size $(25,40,75,120$ and 2000 acres); cost per acre of development rights $(\$ 2,000, \$ 4,000, \$ 6,000, \$ 8,000$, and $\$ 10,000$ ); farm type (crop, horse/livestock, and orchard/nursery); percent of parcel in forest $(10 \%$ or $40 \%)$; proximity to already protected farmland (adjacent or not adjacent); percent of parcel's original road frontage that has been subdivided and developed (none, 25\%, and 50\%); owner's primary occupation (farming, not farming); pace of development (rapid or moderate); annual gross farm receipts $(\$ 12,000$ or $\$ 60,000$ per year); and expected long-term economic viability of farming in the area (poor or good). A survey of hypothetical combinations of these attributes was conducted using both graphic and word descriptions of the hypothetical bundles of farm attributes. Ratings and rankings for each hypothetical farm were then used to estimate an index reflecting residents' preferences.

There are many advantages of data collection through a survey of this nature. A conjoint survey can be administered to a wide range of audiences, and the results are easily interpreted. In this case, the results can be used by PDR program officials to make objective decisions regarding which candidate farms to protect. Alternatively, the results can be used to evaluate the program as a whole after farms have been pro- tected. The question then becomes "Did the program maximize public benefits through its allocation of PDR funds?"

Agriculture Environmental Management and Community Relations. Nathan Leonard, ${ }^{1}$ Duncan Hilchey, ${ }^{2}$ and Bernadine Italiano. ${ }^{3}$

${ }^{I}$ PRO-DAIRY, Cornell Cooperative Extension, ${ }^{2}$ Farming Alternatives Program, and ${ }^{3}$ Cornell Cooperative Extension, Ithaca, NY 14853.

Agriculture environmental management is receiving high priority from both farm and nonfarm interests. Complaints frequently arise around larger farm operations even when they maintain excellent environmental management. Cornell Cooperative Extension is publishing material encouraging greater understanding, communication, and conflict resolution between farmers and neighbors to support sustainability of agriculture in communities.

Agriculture is often a preferred land use because it has considerably less environmental impact than most alternative uses. However, as nonfarm residents come in contact with agriculture, conflicts occasionally arise. Even commonly accepted farm practices may disturb communities. Frequently, environmental concerns are the triggering issues.

Farm and neighbor relations are often strained as farms increase in size. A landmark lawsuit in New York (C.A.R.E. vs. Southview Farm) offers an extreme example of what can happen if a community group takes issue with environmental management on a farm. Although manure odor was the triggering concern, the issues brought to court involved accidental manure spills, manure runoff from fields, and elevated nitrate levels in neighboring wells. The cost of this case would exceed the ability of most farms to pay.

A new trend is for farms to open communications with neighbors. Visiting neighbors, writing letters, hosting meetings, and inviting people to the farm are among the strategies being used to communicate. Farmers also are asking people to request manure spreading adjustments to avoid interfering with special events.

Farmers also have concerns. These range from property line disputes to vandalism. Communications and proactive conflict resolution skills are enabling farmers and 
neighbors to solve their concerns. Greater understanding often dissolves issues. Sometimes farmers have no awareness of a problem and are willing to change practices even at great expense.

\section{National and Provincial Policies on Agriculture and the Environment}

*"The Living Countryside": Maintaining Sweden's Agrarian Landscape. David Vail. Department of Economics, Bowdoin College, Brunswick, ME 04011.

Sweden, like its northern European neighbors, has a long history of measures to maintain an open and varied agrarian landscape. The intention has been to counteract three tendencies: loss of arable land to development; reversion of open land to forest; and landscape "rationalization," a part of agricultural industrialization. The latter tendency has been reinforced by policies encouraging increased farm scale, specialization and mechanization.

In the late $1980 \mathrm{~s}$, two farmland protection measures were introduced: a multiyear contract system that pays rents for maintenance of biologically rich, scenically beautiful, and culturally valued meadows and pastures; and conversion grants to restore wetlands, hedgerows, and other landscape elements previously lost through rationalization. Taking account of the land's "public goods" value, these initiatives were cost- effective.

The political economy behind these initiatives centered on the state's search for low cost ways to reduce food surpluses, but it also was influenced by farm interest groups' "rent protecting" behavior, the Department of Environmental Protection's critique of agriculture's environmental impacts, and environmental organizations' mobilization of public opinion behind farmland protection.

Other agricultural policies of the late 1980s, all intended to reduce farm output, also affected the rural landscape. Three measures - financial subsidies for conversion to organic farming, animal rights legislation mandating increased grazing, and a cover crop requirement in the voluntary acreage setaside - had positive landscape effects. However, subsidized afforestation of arable land, particularly in already heavily forested regions, contradicted the goal of an open and varied landscape.

Two major policy changes in the $1990 \mathrm{~s}-$ a market-oriented food policy (1990) and European Union membership (1995)have had complex and contradictory effects on both the extent and the qualities of Sweden's agrarian landscape.

*The Provision of Countryside Amenities: External Benefits of Agricultural Production in Mountainous Regions. Franz Hackl and Gerald J. Pruckner. Department of Economics, University of Linz, A-4040 Linz/ Auhof, Austria.

This paper covers nonmarket services provided by farmers for recreational and residential purposes in several Central European regions. A regionally specified general equilibrium model is used to derive the efficiency conditions for a competitive equilibrium to guarantee a Pareto optimal outcome, and theoretical conclusions regarding compensation payments are drawn. We also present compensation models already used in Central Europe and assess them from an economic perspective.

The empirical analysis focuses on tourists' willingness to pay (WTP) for the provision of agricultural landscape services in Austria. The mean and median WTP of vacationers is $0.65 \mathrm{ECU}$ and $0.25 \mathrm{ECU}$ per person per day, respectively, with the figures varying according to the tourists' nationality. A comparison of these measures with current voluntary compensation payments made to farmers for preserving an agricultural countryside in several Austrian tourism communities suggests that results of hypothetical contingent valuation are of the right order of magnitude for the value of recreation-related agricultural services.

From an agricultural policy perspective, increased direct subsidies to farmers for the provision of countryside amenities and the application of environmentally sound production measures combined with a decrease of indirect price supports represent win-win options. Environmental improvements can be expected simultaneously with the stabilization of agricultural income levels, diminishing intrasectoral income differences, and the development of economically disadvantaged rural regions in Central European countries.
*Integration of Environmental Objectives into Agricultural Policy and Law in the Netherlands. Victor Bekkers and Jonathan Verschuuren. Faculty of Law, Tilburg University, P.O. Box 90153, 5000 LE Tilburg, The Netherlands.

In the Netherlands, agriculture and the protection of the environment, especially of nature, have long been closely related. On the policy level, the same Department (Department of Agriculture, Fisheries and Nature) is responsible for both agriculture and protection of nature. This has influenced nature protection policy and legislation. A good example of how farmers are stimulated to preserve nature is the so-called "nature management contract": instead of imposing obligations and prohibitions by law, competent authorities can make contracts with individual farmers in which the farmers agree to run their farming business in a more ecologically balanced way. If they agree, the government compensates the farmers for possible reduction in profits that arise from this way of farming. The European Union strongly supports such measures.

More generally, we have observed a trend toward more external integration. This means that no longer is all environmental policy and law integrated into one Environmental Policy Plan or one Environmental Management Act. Instead, experience proves that integration of environmental objectives (quality goals) into each sectoral field of policy (e.g., agriculture) leads to better results. Internalization of environmental interests can be reached only when fully supported by the people in the relevant policy field (governmental authorities, farmers' unions and individual farmers).

We review the consequences of these new forms of steering: external integration of environment into agricultural policy and law; and, as an example, the nature management contract as an instrument to combine agricultural activities with protection of nature.

The Evolution of Environmental Enhancement Programs for Agriculture in Ontario. Stewart Hilts. Centre for Land and Water Stewardship, University of Guelph, Guelph, Ontario N1G 2W1, Canada. 
Over the past five years, a coalition of farm groups in Ontario has developed a comprehensive Environmental Farm Planning Program. With extensive government support, it has been subject to a pilot evaluation and is now being implemented with a target of reaching 14,000 farm families in four years. In this paper the development of past environmental enhancement programs for agriculture and of the Environmental Farm Planning program are described. This program is one of the most comprehensive of such programs in the world, and is one of the few that have been organized and implemented by farm organizations themselves. Within it are numerous examples of environmentally positive agricultural practices in the context of a general strategy to enhance positive agriculture/environment interaction. The role of the rural landowner and the contribution of private stewardship to the enhancement of ecologically sustainable rural landscapes provide a theoretical context for the paper. Policy options are considered, with the conclusion that a voluntary, educational policy approach may provide greater measured benefits on the ground in the long run than regulatory or financial incentive policy options.

\section{Agricultural Development and the Environment}

*Resource Systems Analysis: Linking Agriculture and Environment in Central Java, Indonesia. Valerie Sexton. 63 St. Margaret's Bay Rd., Apt. 25, Halifax, Nova Scotia B3N 1J8, Canada.

The island of Java is very fertile because of deposits from volcanic activity. In the lowlands, agriculture is quite stable, ecologically and economically. However, upland agriculture, as inherited from colonial times, is less economically beneficial and quite ecologically damaging because of accelerated soil erosion.

This need not be the case. One approach that permits a "win-win" situation for both upland agriculture and the environment has been attempted in Indonesia. The Faculty of Forestry at the University of Gadjah Mada, Yogyakarta, Indonesia, is in the midst of implementing a system of sustainable agriculture in the uplands of the Mangunan/ Girirejo area of Central Java.
Resource Systems Analysis is a useful way to visualize how agriculture and related processes affect the environment and are in turn affected by it. The Resource Systems Framework indicates relationships among the physical environment and its functions, the main resource being processed, the final product, inputs required, by-products, distribution of the product, and consumption patterns as influenced by social organization, demographics, and political economy.

My research in Indonesia in 1992 specified the linkages that existed as the attempt was made to switch to more "environmentally friendly" types of agriculture. This occurred in response to the danger of loss of livelihoods from upland farming where agricultural methods were depleting the environment that ultimately had to sustain them.

Specifically, the extent of the intertemporal constraint faced by upland farmers in switching to tree and multicropping forms of agriculture was examined in terms of credit provisions: the capital needed; the capital available; and the best manner in which to raise and administer this capital according to existing social, political and economic institutions.

The case study indicates not only how to attain enhanced agricultural productivity and prevent pollution from pesticide runoff, but also how sound agricultural practices help to maintain watersheds, enhance water supplies, reintroduce native species, and maintain biodiversity; all of which in turn, sustain agriculture.

\section{A Sustainable Alternative to Modern Rural Underdevelopment in a Period of Interna- tional Integration. David Barkin. Univer- isidad Autónoma Metropolitana, Apartado 23-181, 16000 Xochimilco, DF, Mexico.}

The modernization of agriculture by the introduction of the Green Revolution technological packages impoverished small-scale farming communities and pushed institutions to discourage the use of intercropping patterns in favor of monocropping. Traditional multiproduct rural production systems have been threatened by the decline in the value of tradable products as international competition strongly influenced local market prices. Peasant producers are being forced to abandon their communities or are being pushed into more fragile ecosystems.

An alternative development model for sustainable regional development is being implemented in a depressed region of central Mexico. A diversified agricultural and agroforestry program is being combined with agro-industrial production along with community provision of on-farm services for recreation, eco-, nature- and cultural tourism, and environmental protection. This paper evaluates the conditions that led to the decline of the region and the social and productive processes being developed for its transformation.

*Are Productivity Enhancing, Resource Conserving Technologies a Viable "WinWin" Approach in the Tropics? The Case of Conservation Tillage in Mexico. Olaf Erenstein. Natural Resources Group, CIMMYT Economics, Apdo. postal 6-641, 0660 Mexico DF, Mexico.

Agricultural development experiences in the tropics suggest that addressing just productivity is generally unsustainable, whereas expensive resource-conserving practices are not necessarily economically viable. Productivity-enhancing, resourceconserving technologies opt for the middle ground, simultaneously addressing agricultural and environmental issues to achieve sustainable agricultural development. As such, these technologies have a "win-win" potential because they serve both agricultural and environmental interests.

Conservation tillage is an example of a productivity-enhancing, resource-conserving technology, as it potentially both reduces soil degradation and increases productivity. However, an array of agro-ecological and socioeconomic factors determine the impacts of the technology, both agricultural and environmental. Most of these factors are specific to the farming systems and environmental conditions of the tropics. This paper specifically reviews some advantages and disadvantages of conservation tillage in maize-based farming systems in the Mexican tropics. It concludes that productivityenhancing, resource-conserving technologies such as conservation tillage are viable only in those locations where they actually would achieve their "win-win" potential. 